\title{
Chanopsis lombardi (Teleostei, Osteoglossiformes) from the continental Lower Cretaceous of the Democratic Republic of Congo. Comments on the evolution of the caudal skeleton within osteoglossiform fishes
}

\author{
LOUIS TAVERNE
}

Résidence “Les Platanes", Boulevard du Souverain, 142 (Box 8), B-1170 Brussels, Belgium; louis.taverne@gmail.com.

ABSTRACT. The skull, pectoral girdle, vertebrae, caudal skeleton and scales of the osteoglossiform teleost Chanopsis lombardi from the continental Lower Cretaceous of the Democratic Republic of Congo are studied in detail. On the basis of the caudal characters and scales, Chanopsis is considered to represent the most primitive member of the family Osteoglossidae sensu lato (including Pantodontidae and Arapaimidae), whereas the Singididae (Singida and Chauliopareion) are shown to correspond to another lineage of osteoglossiform fishes, clearly distinct from the Osteoglossidae.

KEYWORDS: Teleostei, Osteoglossiformes, Chanopsis lombardi, osteology, caudal skeleton, phylogenetic relationships, continental Aptian-Albian, Democratic Republic of Congo.

RÉSUMÉ. Chanopsis lombardi (Teleostei, Osteoglossiformes) du Crétacé inférieur continental de la République Démocratique du Congo. Commentaires sur l'évolution du squelette caudal chez les poissons ostéoglossiformes. Le crâne, la ceinture pectorale, les vertèbres, le squelette caudal et les écailles du téléostéen ostéoglossiforme Chanopsis lombardi, du Crétacé inférieur continental de la République Démocratique du Congo, sont étudiés en détails. Les caractères caudaux et les écailles de Chanopsis situent ce poisson comme le membre le plus primitif de la famille des Osteoglossidae sensu lato (incluant les Pantodontidae et les Arapaimidae), ceux des Singididae (Singida et Chauliopareion) montrent que cette famille représente une lignée distincte des Osteoglossidae.

MOTS-CLÉS: Teleostei, Osteoglossiformes, Chanopsis lombardi, ostéologie, squelette caudal, relations phylogénétiques, AptienAlbien continental, République Démocratique du Congo.

\section{Introduction}

The continental Lower Cretaceous deposits in the "Congolese Cuvette" and the surrounding zones (Democratic Republic of Congo) belong to two different units, the lower Loia Formation and the overlying Bokungu Formation. The Loia Formation is composed of red and green sandstones with some thin layers of bituminous shales, while the Bokungu Formation consists of red sandstones and shales (Cahen et al., 1959, 1960; Casier, 1961). Sometimes, the Bokungu Formation is considered as the upper member of an enlarged Loia Formation sensu lato (Colin, 1994, Fig. 2).

The precise age of these formations has been a major point of discussion for quite a long time. Both were initially considered to belong to the uppermost Jurassic or the lowermost Cretaceous

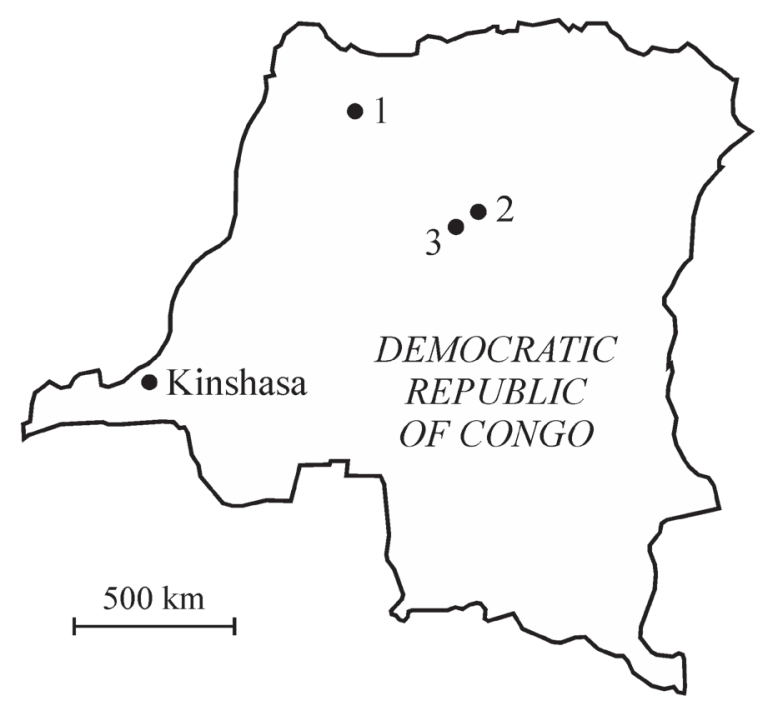

Figure 1. Map of the Democratic Republic of Congo with the localization of (1) the Molimba Plantation, on the Mongala river, (2) Yakoko, on the Tatale river, and (3) Yamangi Moke.
(Cahen \& Lepersonne, 1954). Subsequently, Grekoff (1957, 1960), Casier (1961, 1969a,b) and Defretin-Lefranc (1967), referring to the ostracod, the fish and the phyllopode assemblages respectively, assigned both the Loia and the Bokungu Formations to the Wealden, an imprecise dating, which embraces several subdivisions of the continental Lower Cretaceous (Valanginian to Barremian). However, the presence of three small euteleosts (Taverne, 1975) in the fossil fish fauna of the Loia Formation at Yamangi Moke, Oriental Province (Fig. 1), indicates that those beds are not older than the Aptian, the geological stage during which the first Euteleostei appeared. Pinto \& Sanguinetti (1962), reviewing the ostracod fauna, also referred the Loia Formation to the Aptian. Finally, Maheshwari et al. (1977), on the basis of spore content, assumed its age to be comprised between the Albian and the lowermost Cenomanian. Today, the Loia Formation is reported to the Aptian-Albian interval and the Bokungu Formation to the Albian and eventually the early Cenomanian (Lepersonne, 1977; Colin, 1994).

The rather poor fossil ichthyofauna of both formations is represented by fragmentary and badly preserved material (Casier, 1961, 1969a). The most interesting fish is undoubtedly Chanopsis lombardi Casier, 1961, a large teleost probably reaching around 1 meter in length and which is known by a complete cranial vault, a few other skull and pectoral bones, ribs, vertebrae and scales. It was found in the Loia Formation, which is cropping out along the Tatale River near the village of Yakoko in the Oriental Province (Fig. 1). Casier (1961, p. 59) included this species in the gonorynchiform family, Chanidae. Later, Taverne (1984) showed that Chanopsis lombardi was a member of the Osteoglossiformes (= bonytongues), an order of archaic teleosts belonging to the super-order Osteoglossomorpha and still existing today in South America, Africa, East Asia, Australia and New Guinea.

Some large caudal vertebrae belonging to a teleosteantype caudal skeleton, fossilized in volume, figured among the undescribed material. They were found in the Bokungu Formation on the Mongala River near the Molimba Plantation in the Equator Province, Ubangi region (Fig. 1). Casier (1961, p. 71) only mentioned this find as "des vertèbres ... appartenant à la région caudale d'un grand téléostéen" and referred it with some doubt to an indeterminate ichthyodectid fish (chirocentrid in Casier's paper), another large teleost represented in the Congolese Lower Cretaceous deposits by a few large teeth and 
some vertebrae. A more complete mechanical preparation of this rather well preserved caudal skeleton allowed to disengage some osteological structures embedded in the substratum and permitted to attribute this specimen to a large primitive osteoglossiform and not to an ichthyodectid.

This primitive osteoglossiform caudal skeleton has to be attributed to Chanopsis lombardi, as this taxon is the only Lower Cretaceous representative of the entire order of Osteoglossiforms within the whole African continent and is also one of the most primitive members of that fish order (Taverne, 1998, Fig. 22). As a consequence, it can be concluded that at least two large teleosts occurred in the Lower Cretaceous of the Democratic Republic of Congo, Chanopsis lombardi and a second possibly ichthyodectid species known from isolated teeth and vertebrae.

The aim of the present paper is to re-describe the osteology of Chanopsis lombardi, emphasizing some cranial, pectoral and scale structures that neither Casier (1961) nor Taverne (1984) have mentioned. The use of a CT-scan also allowed the discovering of some bony fragments of the neurocranium hidden in the substratum under the skull roof of the holotype. The final objective is to describe the caudal skeleton of this osteoglossid fish and to study its implication on the understanding of the evolution of the caudal skeleton within the order Osteoglossiformes sensu stricto (not including Mormyridae, Gymnarchidae and Notopteridae).

\section{Material and methods}

The samples of Chanopsis lombardi belong to the paleontological collections of the Department of Geology of the Royal Museum of Central Africa (MRAC), Tervuren, Belgium. They have been studied with a stereomicroscope Leica MZ8. The drawings of the figures were made by the author with a camera lucida. Aspersions with ethanol were used to improve the observations.

The CT-scan reconstruction used for the present study was performed at the Universitair Ziekenhuis - Gasthuisberg of the Katholieke Universiteit of Leuven (KULeuven), Belgium.

The material used for comparisons in the chapter "discussion" comes from the Muséum national d'Histoire naturelle of Paris (MNHN), the Natural History Museum of London (NHM), the Royal Institute of Natural Sciences of Belgium (IRSNB) and the Royal Museum of Central Africa.

\section{Systematic paleontology}

Division Teleostei Müller, 1846

Superorder Osteoglossomorpha Greenwood et al., 1966

Order Osteoglossiformes Berg, 1940
Suborder Osteoglossoidei Regan, 1909

Family Osteoglossidae Bonaparte, 1832

Genus Chanopsis Casier, 1961

Type species: Chanopsis lombardi Casier, 1961 (by monospecificity)

\section{Chanopsis lombardi Casier, 1961}

Holotype. MRAC RG 13.608a-z $\mathrm{z}^{6}$, a few plates with dispersed bony elements of one large fish, comprising a cranial vault (near $17 \mathrm{~cm}$ long), some isolated skull and pectoral bones, vertebrae, ribs, one hypural, fin rays and scales, from the Loia Formation on the Tatale river near Yakoko, Oriental Province, Democratic Republic of Congo (Fig. 1). The dispersion of the bones probably is due to a post mortem action of scavengers.

Other material. MRAC RG 13.635, a left hypercoracoid (= scapula), from the Bokungu Formation on the Mongala river, near the Molimba Plantation, Equator Province, Ubangi region, Democratic Republic of Congo (Fig. 1). MRAC RG 13.636, a complete caudal skeleton from preural vertebra 7 to ural vertebra 2 (12 cm long), with the neural spine of preural vertebra 8 also preserved, from the Bokungu Formation on the Mongala river, near the Molimba Plantation, Equator Province, Ubangi region, Democratic Republic of Congo (Fig. 1). Some fragments of scales are associated to the caudal skeleton.

Emended diagnosis. Large low-bodied osteoglossid fish. Lozenge-shaped dermethmoid fitted in a notch between the two frontals. Large nasals in contact under and anteriorly to the dermethmoid. Broad frontals with an anterior lateral wing-like expansion. Large parietals meeting in the midline. Supraoccipital bearing a long crest. An occipito-dorsal fossa present between the parietal, the epiotic and the supraoccipital. Supraorbital and otic sensory canals not connected. Large triangular entopterygoid bearing some teeth on its upper border and covered with denticles. Ectopterygoid and palatine fused and covered with denticles. Hyomandibular with a large articular head, a short processus opercularis, an anterior wing-like expansion and a short ventral branch. Long curved symplectic, with a spatulated dorsal extremity. Only two large posterior infraorbitals covering the cheek. Preopercle with a long dorsal branch and a broad, very short ventral branch. Large oval opercle ornamented with ridges. Reduced subopercle. Large hypercleithrum. Cleithrum with both branches well developed. One small postcleithrum. Long and broad hypocoracoid. First haemapophyses short and ventrally located on the centra. Last haemapophyses long and laterally located on the centra. Neural and haemal spines and ribs short. Epineurals fused to neural arches. Neural spines present
Figure 2. Chanopsis lombardi Casier, 1961. Reconstruction of the skull roof of the holotype MRAC R.G. 13.608a, y, z.

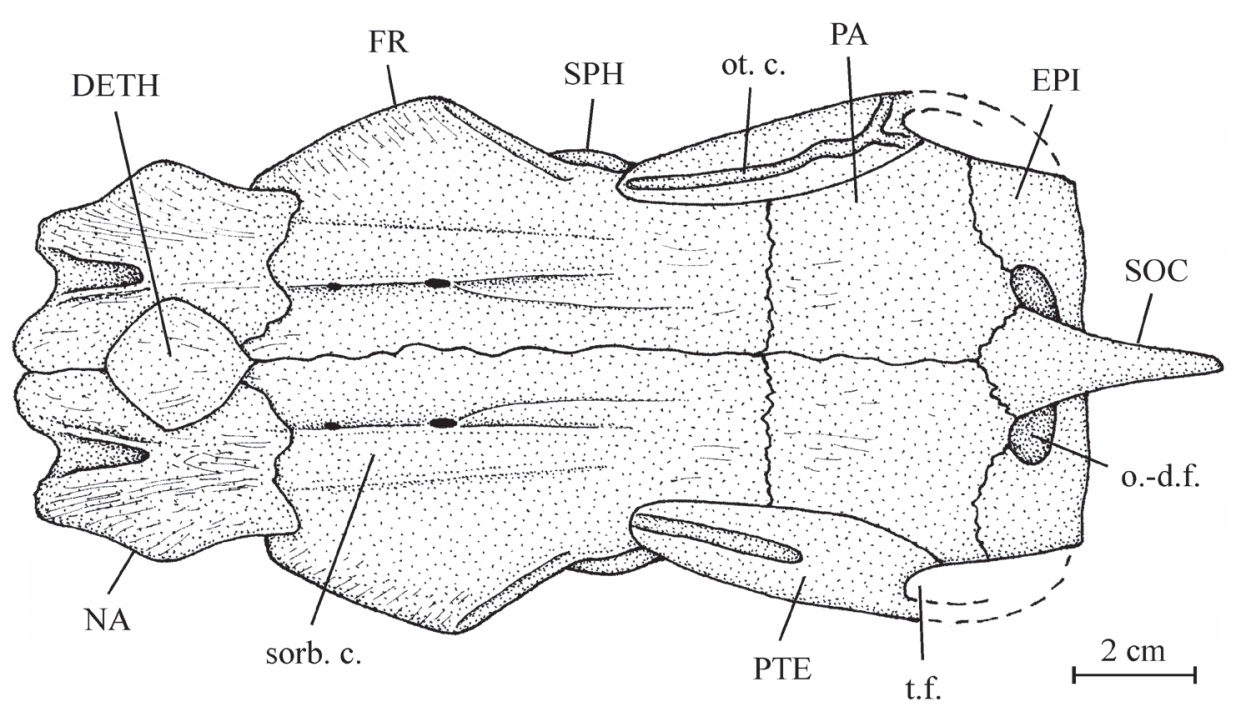


on preural vertebra 1 and ural vertebra 1 and no free epural. Three uroneurals. Ural vertebra 2 not shortened. Six autogenous hypurals. Third hypural articulated with the rear of ural vertebra 2. Scales partly reticulated, with squamules and pre-squamules.

\section{Osteology}

\section{1. - The skull (Figs 2-8)}

The dermethmoid (= rostral) $(13.608 \mathrm{y})$ and one of the two nasals $(13.608 \mathrm{z})$ are preserved as isolated pieces that have been separated from the skull roof during the fossilization. The dermethmoid is a small, flat and more or less lozenge-shaped bone. The nasal is large, broad and thick. When articulated with the frontal, the nasal extends anteriorly and under the dermethmoid. The same relation between the nasals and the dermethmoid exists in the Eocene osteoglossiform Phareodus Leidy, 1873 (Taverne, 2009b, figs 6-8). The nasal bears in its middle the anterior part of the supraorbital sensory canal. The canal is partly open anteriorly and posteriorly but the posterior opening seems to be due to a breaking during the fossilization. The vomer and the other bones of the ethmoid region are unknown.
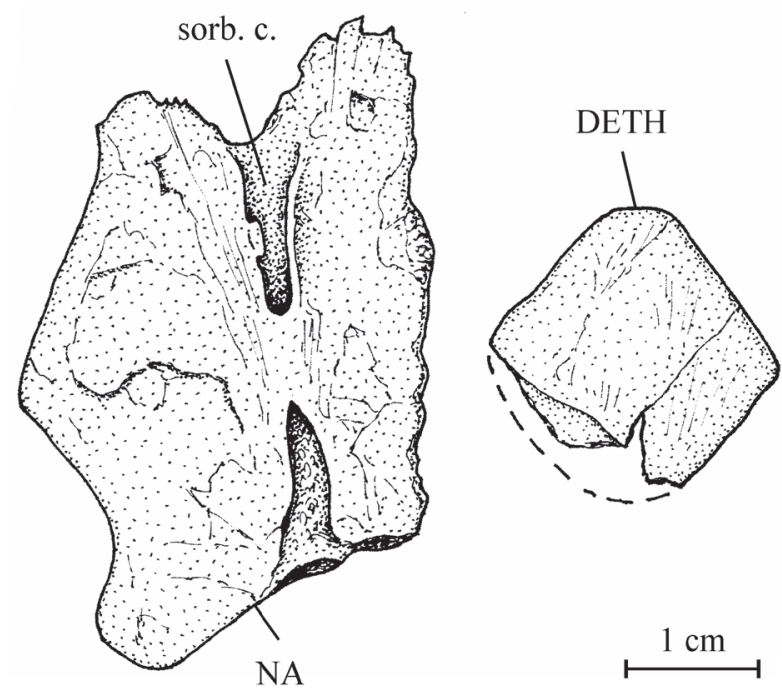

Figure 3. Chanopsis lombardi Casier, 1961. Left nasal (MRAC RG 13.608z) and dermethmoid (= rostral) (MRAC RG 13.608y).

The remaining skull roof is preserved in one piece (13.608a). The frontals are broad and exhibit an important wing-like expansion of the anterior part of their lateral border, just at the orbital level. The supraorbital sensory canal is broad and well marked on the bone. There is a "V"-shaped notch between the anterior edges of the two frontals for receiving the dermethmoid (= rostral). The parietals are large, nearly square and meet at the midline. The supraoccipital bears a strong and long median crest. An occipito-dorsal fossa is dug on each side of the skull between the parietal, the supraoccipital and the epiotic. The pterotics are long, narrow and they extend largely beyond the anterior extremity of the parietals. The otic sensory canal is narrow and partly open. The supraorbital canal on the frontal and the otic canal on the pterotic are not connected. The autosphenotics are small and located under the frontals just anterior to the pterotics. The CT-scan reveals a deep dilatator fossa located on the left sphenotic just behind the postorbital process.

Fragments of the upper part of the rather large pleurosphenoid and orbitosphenoid are preserved under the right frontal of sample 13.608a, as seen on the CT-scan. Well developed pleurosphenoid and orbitosphenoid are known in the fossil osteoglossid fishes Phareodus and Brychaetus Woodward, 1901 (Taverne, 1978, figs $3,5,21$ ), whereas the orbitosphenoid region remains cartilaginous in the Recent osteoglossid fishes Osteoglossum Cuvier, 1829 and Scleropages Günther, 1864 (Taverne, 1977, figs $43,45,49,72,74)$.

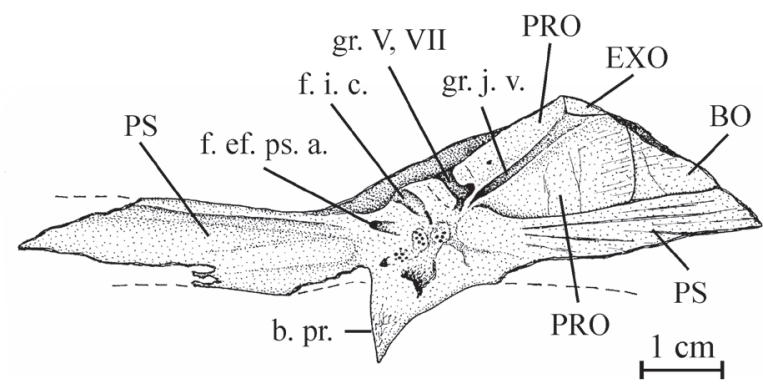

Figure 4. Chanopsis lombardi Casier, 1961. Part of the floor of the braincase (MRAC RG 13.608z'). The external bony layer of the anterior part of the prootic and the intercalar are lost, allowing the internal relief of the prootic to be visible.

Sample $13.608 z^{6}$ exhibits a portion of the neurocranial floor comprising a great part of the parasphenoid and of the left prootic and a very small part of the left exoccipital and of the basioccipital. The intercalar is not present in this specimen. The parasphenoid is a large bone. Its preserved part is almost $10 \mathrm{~cm}$ in length. Only the right basipterygoid process is present. Paired foramens for the pseudobranchial efferent arteries pierce anteriorly at the basis of the processes. More posteriorly at the basis of the processes, there is a pair of grooves for the internal carotids. The region between the processes is severely crushed but some fragments of very small denticles are still visible. The anterior branch of the parasphenoid is toothless. The left prootic has lost a part of its external bony layer and shows its internal relief with a long, rectilinear and deep groove for the jugular vein and, anteriorly, a deep but shorter and laterally oriented groove for the trigeminal and facial nerves (V, VII). The two external foramens for the emergence of those two nerves are visible on another part of the prootic shown on the CT-scan of sample 13.608a. This CT-scan also exhibits the right intercalar with its bony bridge crossing the subtemporal fossa and the two exoccipitals surrounding the foramen magnum. Sample 13.608q shows a toothless fragment of the parasphenoid, the complete left entopterygoid from its inner side and a great portion of the left
Figure 5. Chanopsis lombardi Casier, 1961. Skull roof of the holotype MRAC R.G. 13.608a in left lateral view and some hidden bones revealed by the CT scan.

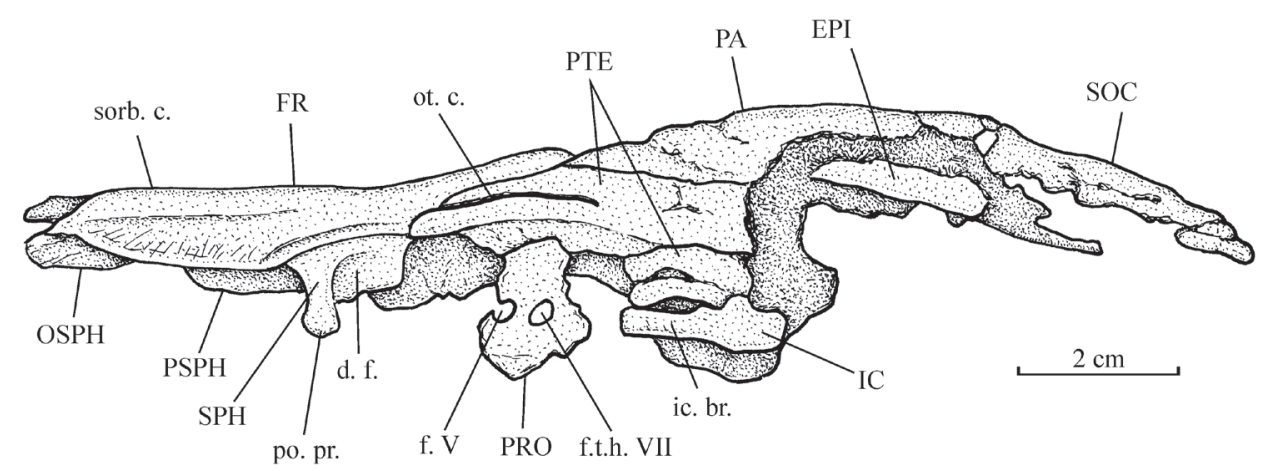




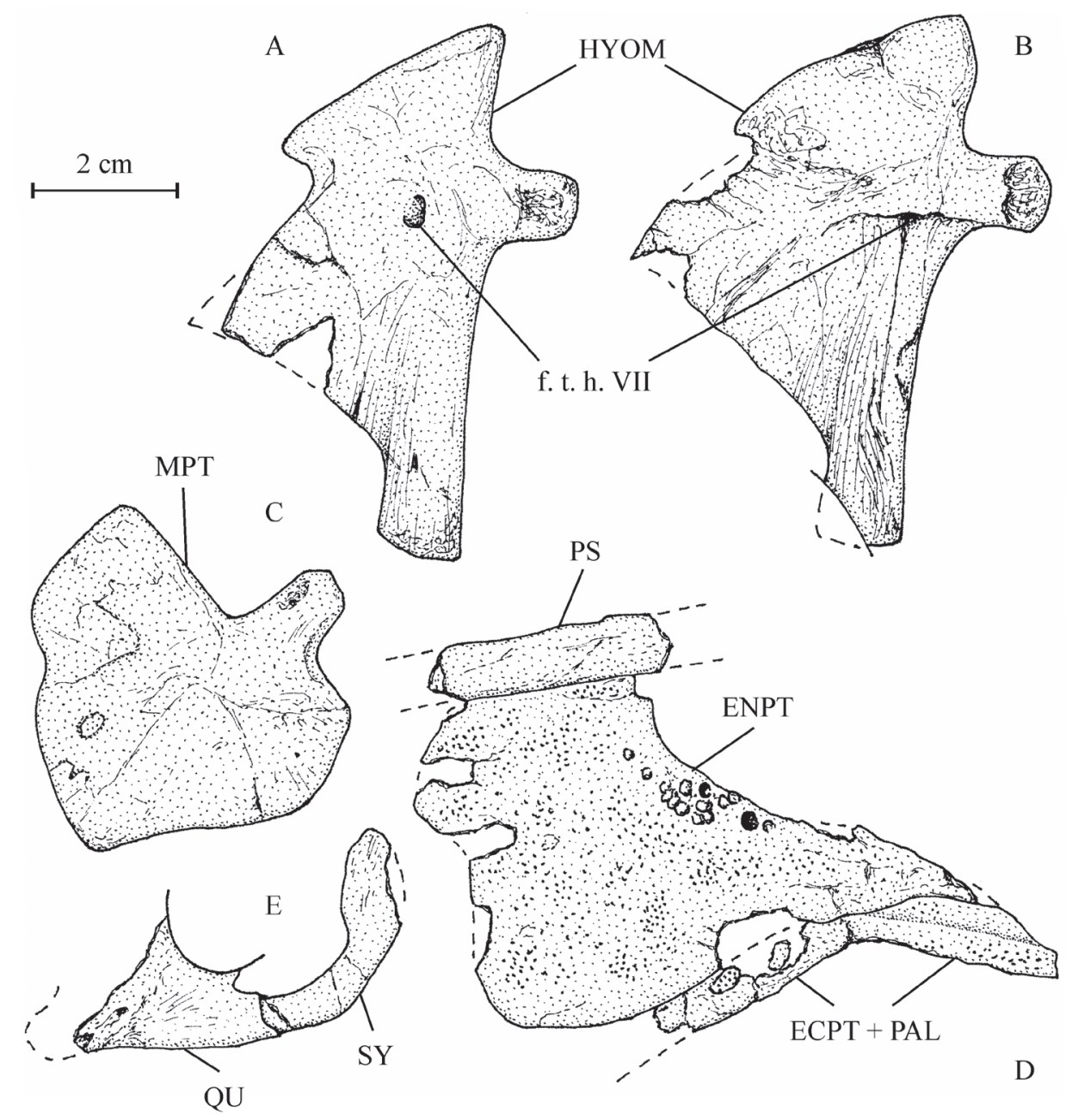

Figure 6. Chanopsis lombardi Casier, 1961. Hyopalatine bony series. (A) right hyomandibular (MRAC RG 13.608e) in inner view, (B) left hyomandibular (MRACRG 13.608d) in external view, $(C)$ right metapterygoid (MRAC RG 13.608f) in external view, (D) left pterygopalatine bones (MRAC RG $13.608 \mathrm{q})$ in internal view, and (E) left quadrate (fragment) and symplectic (MRAC RG $13.608 \mathrm{w}$ ) in external view.

ectopterygoid-palatine. The entopterygoid is a large bone, very deep in its posterior region but much more thinner in its anterior part, a typical shape within Osteoglossiformes. There is a notch on the upper margin of bone. In osteoglossiform fishes, such a notch serves to receive the basipterygoid process of the parasphenoid. Anteriorly to this notch, the oral margin of the bone bears some fragments of big teeth and some large tooth-sockets. Traces of small denticles are visible on practically all the inner surface of the entopterygoid. The ectopterygoid-palatine is long, narrow and covered with small denticles. The metapterygoid (13.608f, g) is almost triangular in shape, with a concave dorsal border and an antero-dorsal corner forming a short process. Only a fragment of the left quadrate is preserved $(13.608 \mathrm{w})$.

The bones of the jaws are unknown. Three orbital bones are preserved $(13.608 \mathrm{~b}, \mathrm{e})$. There are only two large posterior infraorbitals, completely covering the cheek region. The ventral bone is deeper than the dorsal. A small part of a narrow second infraorbital is also present. The dermosphenotic is not preserved but the length of its articulation groove on the rear of the lateral expansion of the frontal shows that it is a rather large bone. The preopercle $\left(13.608 \mathrm{~s}, \mathrm{z}^{2}\right)$ has a long dorsal branch and a broad but very short ventral limb. The opercle (13.608c) is large, more or less oval, deeper than long, with rounded dorsal and posterior borders. The surface of the bone is ornamented with numerous radiating rectilinear ridges reaching the posterior border. The subopercle (13.608t) is very reduced. The interopercle (13.608t) is semi-circular.

\section{2. - The hyoïdeo-branchial skeleton (Figs 6, 8)}

There is a single broad, obliquely oriented articular head on the hyomandibular $(13.608 \mathrm{~d}, \mathrm{e})$. Its ventral branch is rather short but strong and rod-like. The processus opercularis is well developed but short. Anteriorly, the hyomandibular bears an expanded triangular bony wing reaching the metapterygoid. The symplectic (13.608w) is a large bone, all together long, broad, curved and with a spatulate posterior extremity. It considerably outpaces the

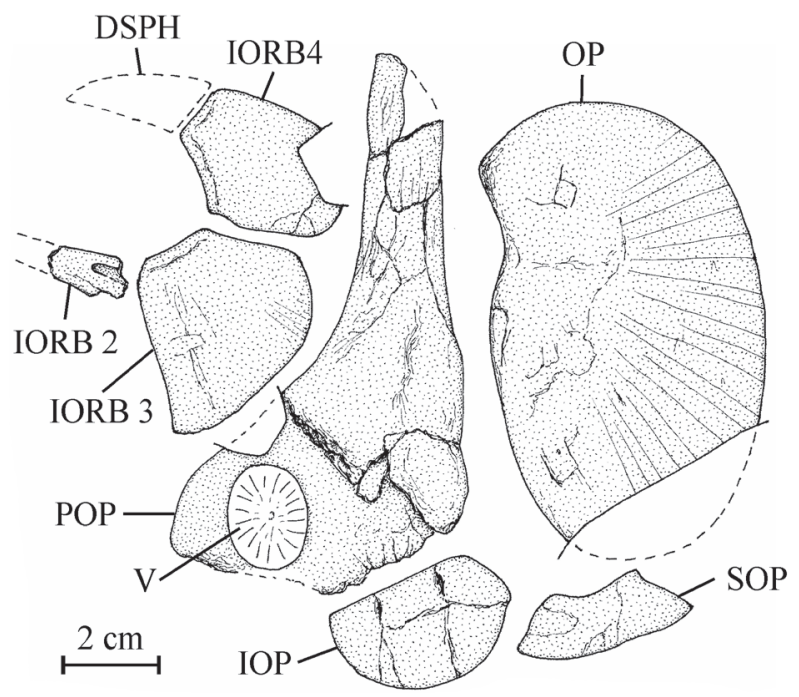

Figure 7. Chanopsis lombardi Casier, 1961. Orbital and opercular bony series. Second (fragment), third and fourth infraorbitals (MRAC RG $13.608 \mathrm{~b}$, e), right preopercle (MRAC RG 13.608s) [reversed], right opercle (MRAC RG 13.608c) [reversed], and left interopercle and subopercle (MRAC RG 13.608t).

quadrate as frequently in Osteoglossiformes.

One anterior ceratohyal is preserved $\left(13.608 \mathrm{z}^{4}\right)$. It is a long and large bone, with the posterior extremity deeper than the anterior one. The middle of the bone is narrow and devoid of 
beryciform foramen. The piece that Casier (1961, p. 60) identifies as a ceratohyal (13.6081) is a large fragment of the cleithrum. The branchial skeleton is lost but a few long needle-like branchiospines are present in the material of the holotype series.

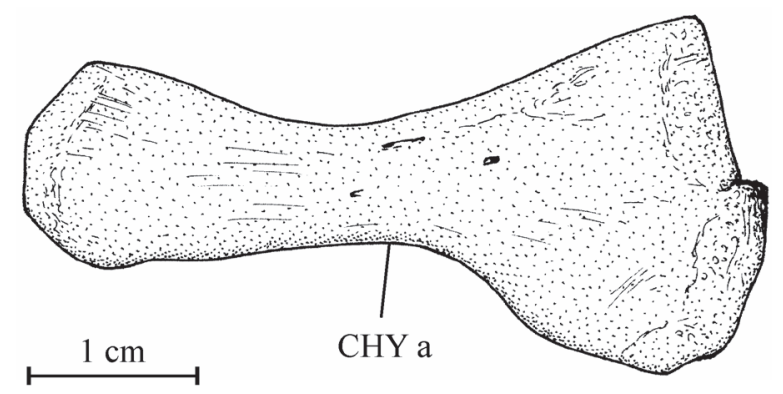

Figure 8. Chanopsis lombardi Casier, 1961. Anterior ceratohyal (MRAC RG $\left.13.608 z^{4}\right)$.

\section{3. - The girdles (Fig. 9)}

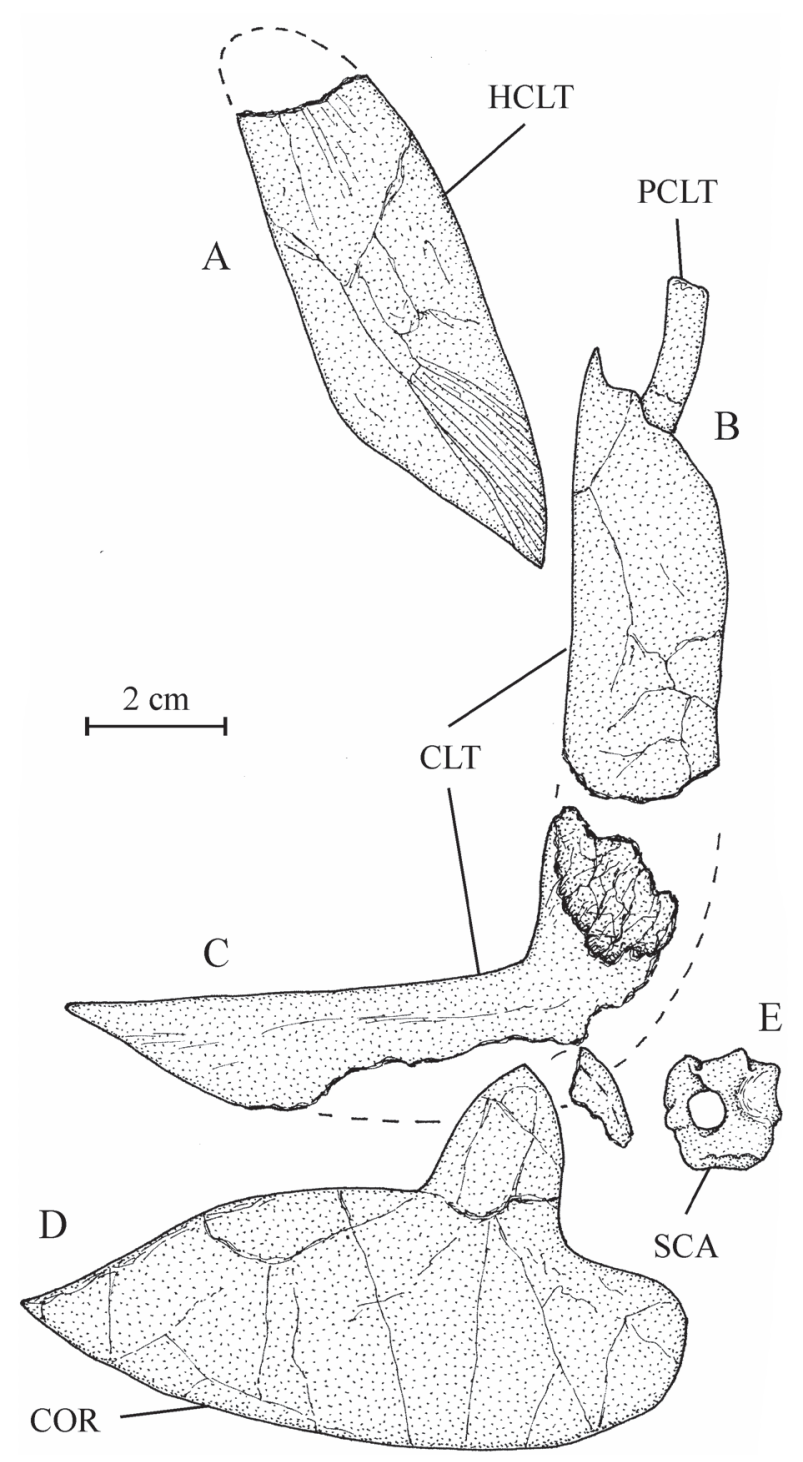

Figure 9. Chanopsis lombardi Casier, 1961. Pectoral girdle. (A) right hypercleithrum (= supracleithrum) (MRAC RG 13.608i) [reversed], (B) dorsal branch of the right cleithrum with the postcleithrum (MRAC RG $13.608 \mathrm{v}$ ) [reversed], (C) ventral branch of the left cleithrum (MRAC RG 13.608u), (D) right hypocoracoid (= coracoid) (MRAC RG 13.608j) [reversed], and (E) left hypercoracoid (= scapula) (MRAC RG 13.635).
The posttemporal is not known. The bone called "posttemporal" by Casier (1961, Fig. 17) is the epiotic. The hypercleithrum (= supracleithrum) $(13.608 \mathrm{~h}, \mathrm{i})$ is a very robust bone, broad and as long as the dorsal branch of the cleithrum. It lacks any sensory canal. The lower part of its surface is ornamented with ridges. The dorsal and ventral limbs of the cleithrum (13.6081, u, v) are elongated and rather narrow. There is a small postcleithrum (also $13.608 \mathrm{v}$ ). The hypercoracoid (= scapula) (13.635) is a small more or less quadrangular bone. It is perforated by a large foramen for the fin nerves and blood vessels and presents a posterior facet for the articulation with the first pectoral ray. Casier (1961, p. 71) referred this piece to a "chirocentrid" fish but the hypercoracoid of the Ichthyodectidae shows three articular facets (Bardack, 1965, p. 50,68 , figs 12,21 ; person. observ.) and not only one as here and in other osteoglossoid fishes. The hypocoracoid (= coracoid sensu stricto) $(13.608 \mathrm{j}, \mathrm{k})$ is a large bone, long and very broad. It bears a well pronounced dorsal process which articulates with the cleithrum and a big rounded posterior process going beyond the level of the cleithrum. The pelvic girdle is not preserved.

\section{4. - The axial skeleton (Fig. 10)}

The vertebrae are rather large, much deeper than long and their lateral faces are ornamented with alveoli and small crests like the centra in Phareodus (Roellig, 1967, Fig. 12). The number of vertebrae is unknown.

The neural and haemal spines and the ribs are rather short in comparison with the size of the centra, a character which indicates that the fish was low-bodied as Brychaetus Woodward, 1901, Foreyichthys Taverne, 1979 and the Recent Osteoglossiformes and not deep-bodied as Phareodus and Musperia Sanders, 1934.

The neural and haemal arches are autogenous. The anterior face of the neural spines is dug along the mid-line by a long vertical groove. In the abdominal region, the haemal arch is formed by a pair of haemapophyses. On the first vertebrae, the haemapophyses are short, ventrally located and they bear on their posterior face an articular gutter for the ribs. The posterior haemapophyses become much longer and they articulate with the lateral faces of the vertebrae. In the caudal region, the haemal arches are closed and bear haemal spines.

Some rectilinear rod-like bones seem to be supraneurals. The ribs exhibit a slightly enlarged articular dorsal head. The last ribs are very slender and still shorter than the first ones. The strongly ossified epineurals are short and fused to the corresponding neural arches.

\section{5. - The fins}

Some strong segmented rays are present in the material but their distal extremities are lost. The segments are narrow. It is not possible to determine to which fins these rays are belonging but some of them exhibit a curved basis, a character certainly corresponding to the pectoral or the pelvic fin.

\section{6. - The caudal skeleton (Figs 11-13)}

The preserved part of the caudal peduncle of Chanopsis is composed of nine vertebrae (13.636). It is rather long and not very deep, a character which probably confirms that the fish was low-bodied.

All the caudal vertebrae since the level of preural centrum 7 are well developed and autogenous, including the ural centra 1 and 2 (U 1 and $U$ 2). Those vertebrae are deeper than long, except $\mathrm{U} 2$ which is smaller, less deep but not shorter than the preceding vertebrae. The flanks of the centra often are ornamented with one or two large alveoli. All the neural arches and spines are autogenous. Both preural vertebrae 1 and 2 (PU 1 and PU 2) bear a well developed neural spine but that on PU 1 is a little shorter and narrower than the preceding spines. The neural spine on $U 1$ is still shorter and thinner than that on PU 1. No free epural is present. On preural vertebrae 5 to 7 , the haemal arches and spines are fused to the corresponding centra, while that of preural vertebra 4 is only partially fused to the centrum. 
A
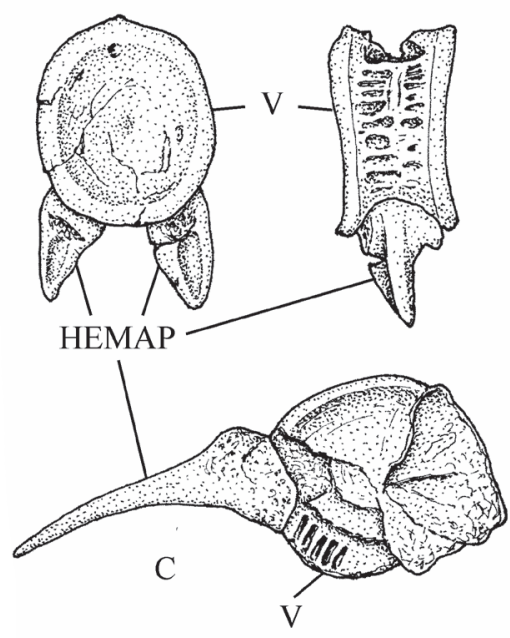

$2 \mathrm{~cm}$

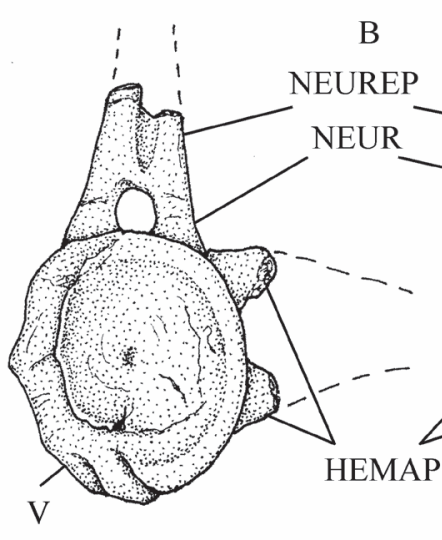

B
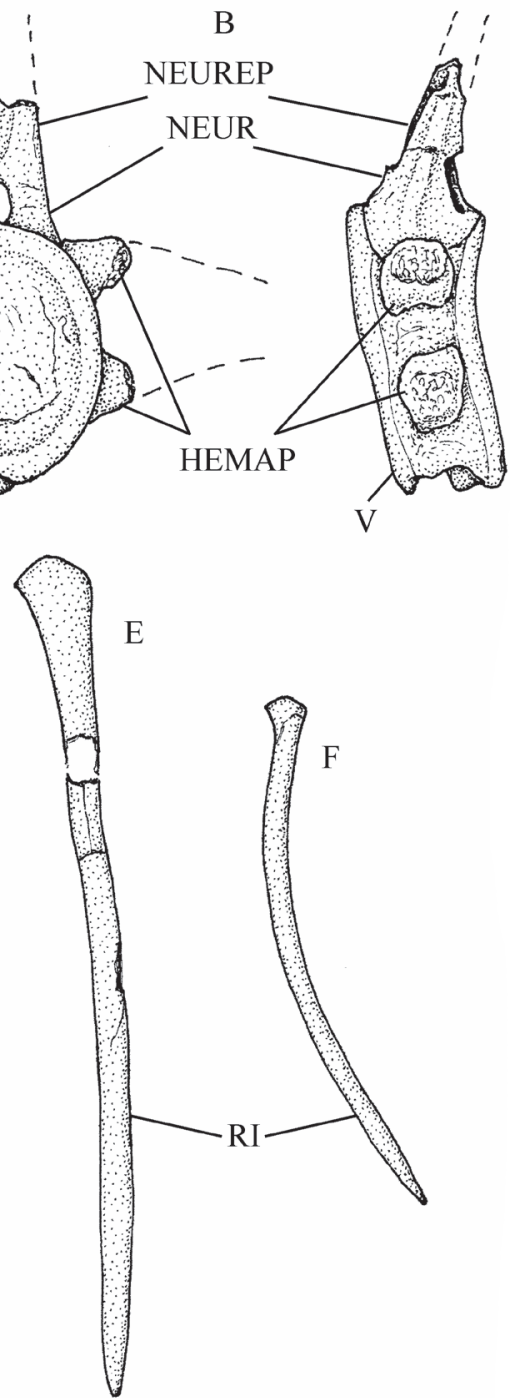

Figure 10. Chanopsis

lombardi Casier, 1961.

Vertebrae and ribs. (A) one of the first vertebrae (MRAC

$\mathrm{RG} 13.608 \mathrm{o}$ ) in posterior

view (at left) and in left lateral view (at right), (B) an abdominal vertebra (MRAC

RG $13.608 \mathrm{o}^{1}$ ) in anterior view

(at left) and in left lateral view

(at right), (C) an abdominal

vertebra (MRAC RG 13.608x)

in anterior view, (D) a vertebra

(MRAC RG $13.6080^{2}$ ) in

anterior view, (E) an anterior rib (MRAC RG 13.608z'), and

(F) a posterior rib (MRAC RG

13.608p).

Figure 11. Chanopsis lombardi Casier, 1961. Caudal skeleton (MRAC R.G. 13.636).

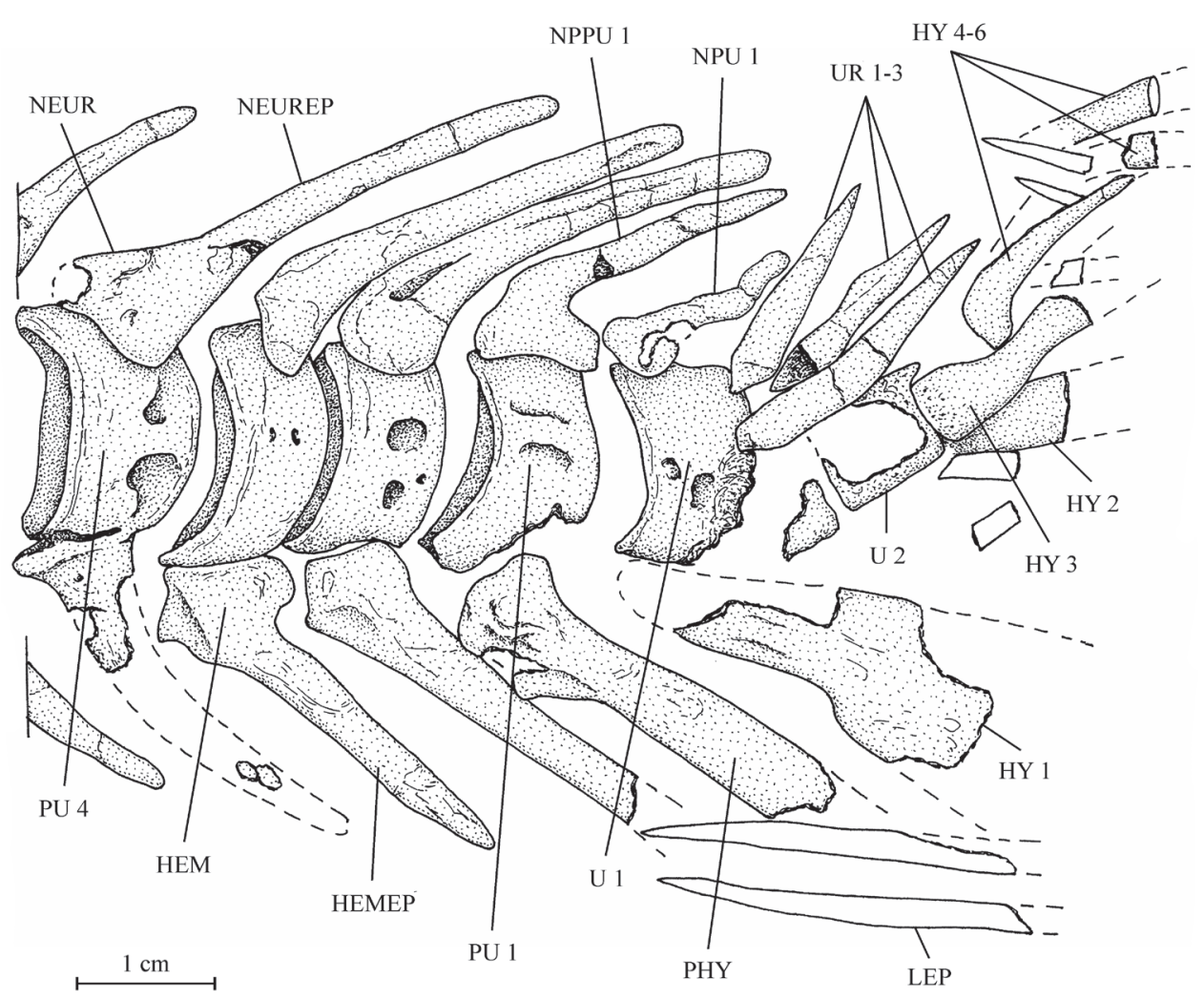


The haemal arches of preural vertebrae 1 to 3 are autogenous. The autogenous parhypural is a little longer and broader than the preceding haemal spines. It does not bear a hypurapophysis. There are six autogenous hypurals (HY 1-6). The first one is a large bone but only partly preserved. However, a complete first hypural $\left(13.608 z^{3}\right)$ is present in the holotype series. Its articular head is long and its distal extremity very broad. The second hypural is rather broad but is displaced by the fossilization and rejected far from the first one. Its proximal part is embedded in the matrix and cannot be disengaged without destroying $\mathrm{U} 2$ and the third hypural. This third hypural is narrower but exhibits an enlarged, truncated head with a large circular and smooth facet that articulates with the rear face of $\mathrm{U} 2$ and not with the ventral face of this centrum as usual in primitive teleosts. The fourth hypural also shows an enlarged proximal head. Only a small part of the fifth hypural is visible; its proximal part remains hidden by the matrix. The sixth hypural has been lost during fossilization but its presence is attested by a large regular pit deeply sunk in the matrix. Three short but rather broad uroneurals (UR 1-3) are present. Anteriorly, they reach the level of $U 1$. There is no trace of urodermals.

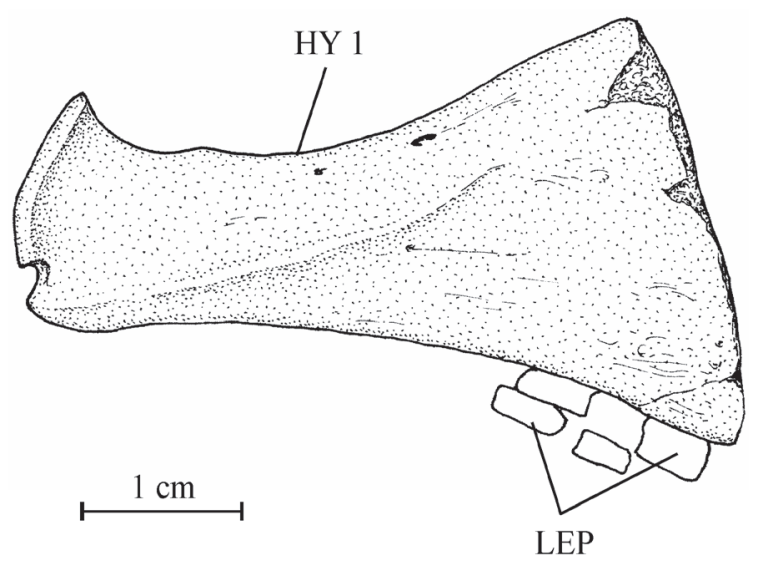

Figure 12. Chanopsis lombardi Casier, 1961. First hypural (MRAC RG $\left.13.608 z^{3}\right)$
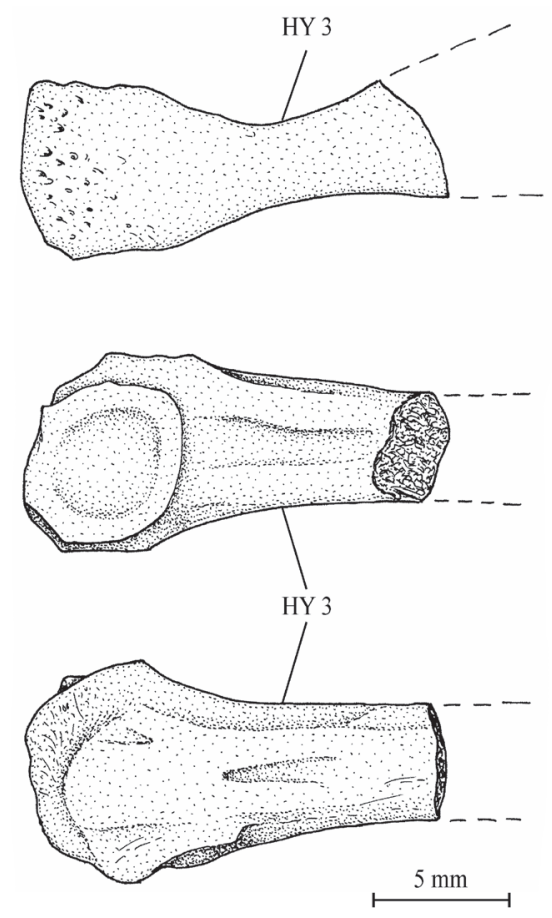

Figure 13. Chanopsis lombardi Casier, 1961. Third hypural (MRAC R.G. 13.636) in left (above), dorsal (middle) and ventral view (below).
Some fragments of big caudal rays are preserved but the number of principal caudal rays is not determinable. A part of the caudal fin is also preserved in the holotype series.

\section{7. - The scales (Fig. 14)}

There are two different morphotypes of large cycloid scales associated with the bones of the holotype series. This difference probably is depending on the localization of the scales on the body.

A large scale (13.608z $\mathrm{z}^{5}$ ) is preserved just above the ceratohyal. A few long rectilinear radii rise out from the nucleus which is close to the border of the scale. Numerous concentric thin circuli are well visible on a great part of this scale and especially on its upper and lower borders.

Some fragments of scales of the same morphotype are associated to the previously described caudal skeleton (13.636). The radii are present, more or less rectilinear and rather numerous but the circuli are not visible. The surface of the scale remains unornamented. Between the radii, the thick whitish upper layer of the scale is fragmented in small rectangular units and many of them are found isolated on the substratum. These small units seem to be the most primitive aspect of the squamules present on the scales of many osteoglossiforms. We can consider them as pre-squamules.

One very large and damaged scale of the holotype series (13.608q) is particularly interesting because it shows the coexistence on the same scale of such small unornamented presquamules between the radii and of large true squamules with a more or less granulated surface and forming a reticulum on a part of the scale.

\section{Discussion}

\subsection{Chanopsis lombardi as a member of the order Osteoglossiformes}

Taverne (1984, p. 585-586) largely developed arguments based on the cranial and pectoral anatomy (expanded lateral border of the frontal, large parietals, medioparietal skull, presence of an occipito-dorsal fossa, only two large posterior infraorbitals, enlarged coracoid, etc.) to prove that Chanopsis lombardi belonged to the Osteoglossiformes and not to the Chanidae. He ranged it in the family Osteoglossidae. Later, Taverne (1998, p. 130, Fig. 22) showed that Chanopsis was one of the most primitive members of the order and not closely related to the Recent Osteoglossidae.

The shape of the nasal and of the entopterygoid, the morphology of the parasphenoid, the presence of complete neural spines on PU 1 and $U 1$ and of squamules on the scales confirm the belonging of Chanopsis to the Osteoglossiformes, as already established by the other cranial and pectoral characters of this fish.

\subsection{The plesiomorphic characters of Chanopsis lombardi within Osteoglossiformes}

The preservation of three uroneurals in Chanopsis proves its primitiveness. Only Xixiaichthys tongxinensis Zhang, 2004, another archaic osteoglossiform from the Lower Cretaceous of China, also presents three uroneurals (Zhang, 2004, Fig. 5C). A few fossil members of this order still possess two uroneurals, as Paralycoptera wui Chang \& Chou, 1977 from the Albian of China (Xu \& Chang, 2009, Fig. 9B), but many extinct and all Recent osteoglossiforms exhibit only one uroneural.

The absence of connection between the supraorbital and the otic sensory canals in Chanopsis is another archaic character which reminds the case of the Lycopteriformes and the Hiodontiformes (Greenwood, 1970, figs 1-4; among others), the two most primitive orders of the Osteoglossomorpha. Within fossil Osteoglossiformes, only the Chinese Xixaichthys 


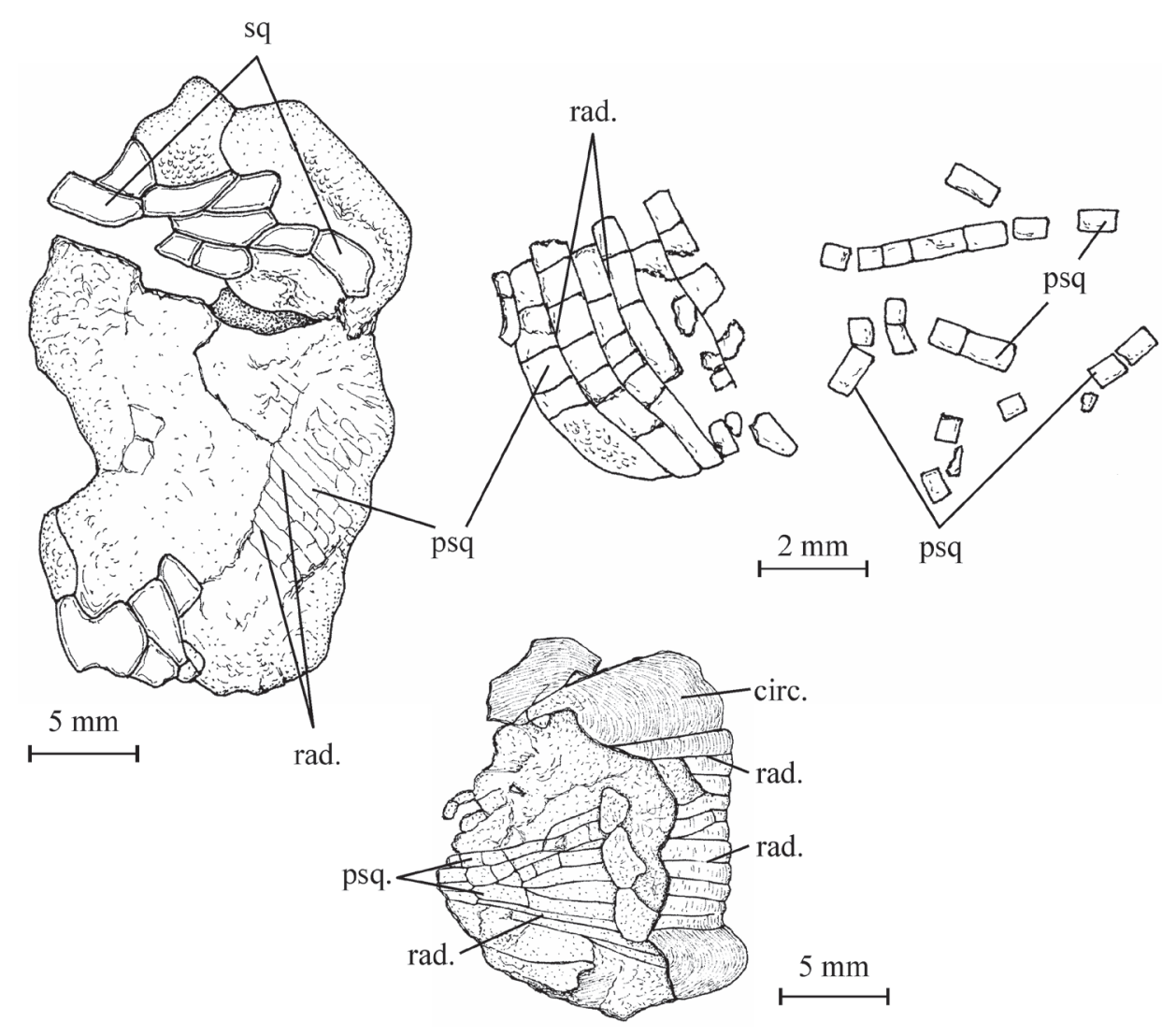

Figure 14. Chanopsis lombardi Casier, 1961. (Above, left) complete scale of the holotype series (MRAC R.G. $13.608 \mathrm{q}$ ), (above, middle) a fragment of scale with pre-squamules (MRAC R.G. 13.636), (above, right) some isolated pre-squamules (MRAC RG 13.636) and (below) complete scale of the holotype series (MRAC RG $\left.13.608 z^{5}\right)$.

tongxinensis and Paralycoptera wui and the African Singida jacksonoides Greenwood \& Patterson, 1967 and Chauliopareion mahengeense Murray \& Wilson, 2005 offer the same archaic pattern (Greenwood \& Patterson, 1967, Fig. 2; Zhang, 2004, p. 516; Murray \& Wilson, 2005, figs 3, 5; Xu \& Chang, 2009, figs 3B, 4B). All other fossil and Recent osteoglossiform species have the two canals connected.

\subsection{The relationships of Chanopsis lombardi within Osteoglossiformes}

Concerning the relationships of Chanopsis within osteoglossiforms, we see that it shares the wing-like expansion of the lateral border of the frontals with some other fossil genera, for instance Phareodus, Brychaetus, Musperia, Cretophareodus Li, 1996, and probably Taverneichthys Kumar et al., 2005 (Taverne, 1978, figs 2-5, 16, 20-22; Taverne, 2009b, figs 5-9, 12; Li, 1994, figs 1, 8; Li, 1996, Fig. 3; Li et al., 1997, figs 2, 3, 8).

Chanopsis also exhibits another very peculiar apomorphy, the presence of a well marked occipito-dorsal fossa between the parietal, the supraoccipital and the epiotic. This remarkable character also exists in a few other fossil osteoglossiforms, such as Phareodus, Brychaetus and Foreyichthys (Taverne, 1978, figs 3, 4, 16, 21, 22; Taverne, 2009b, figs 5, 6, 9; Li, 1994, Fig. 1; Li et al., 1997, Fig. 2A; Bonde, 2008, Fig. 6), but is absent in all Recent members of the order, probably because of the shortening of the occipital region behind the parietals in these species. In the Recent African osteoglossoid Heterotis Cuvier \& Valenciennes, 1846, the occipital region of the braincase is expanded (Taverne, 1977, figs $94,95,104$ ) but the presence of two large posterior cerebral accessory organs (Taverne, 1974, Fig. 1) prevent the expansion of such occipito-dorsal fossae.

Chanopsis has not only true squamules but also pre-squamules on the scales. This character links that genus to the numerous fossil and Recent osteoglossiform fishes in which the scales bear squamules, and places it in a plesiomorphic position in regard to all these species with reticulated scales but in which the presquamules are already lost. Some fossil species, as Xixiaichthys tongxinensis, Paralycoptera wui, Singida jacksonoides and Chauliopareion mahengeense, do not possess squamules on the scales.

\subsection{The evolution of the caudal skeleton within Osteoglossiformes (Figs 15-20)}

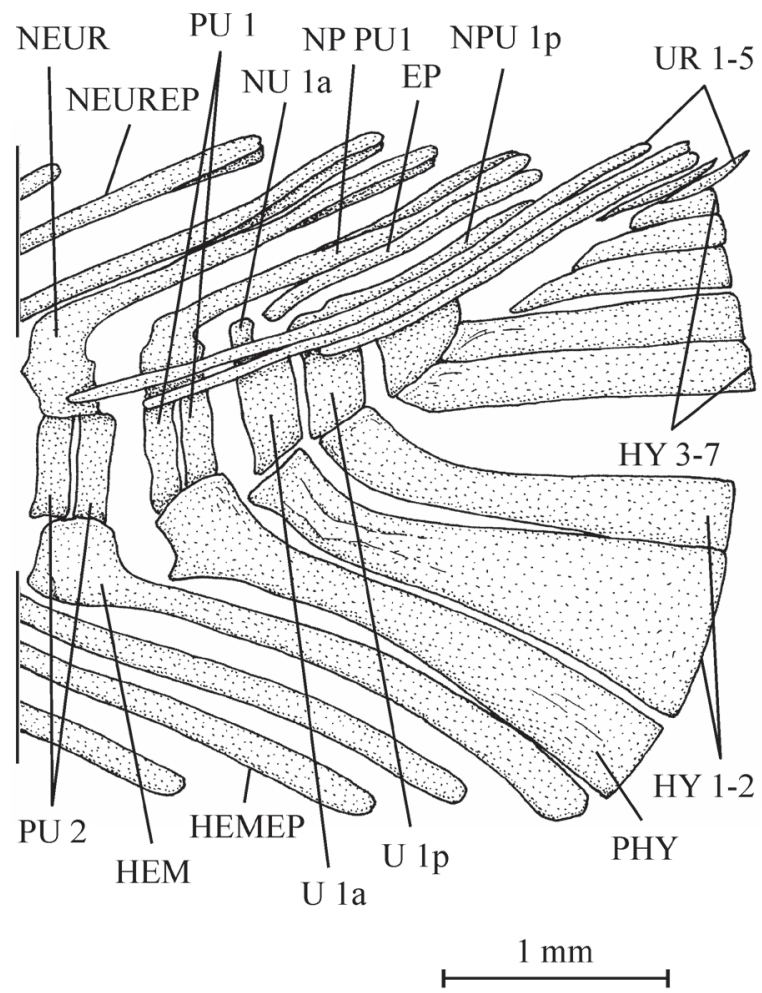

Figure 15. Lycoptera davidi (Sauvage, 1880). Caudal skeleton (MNHN 1927-13-06-10a). 
The most primitive pattern of caudal skeleton within Osteoglossomorpha occurs in some Lycopteriformes, such as for instance Lycoptera davidi (Sauvage, 1880) or Jinanichthys longicephalus (Liu et al., 1963), both from the Lower Cretaceous of China, which still have one free epural, five or six uroneurals, seven or eight autogenous hypurals, often two neural arches associated with $U 1$, and sometimes diplospondyly at the level of the last vertebrae (Fig. 15; Zhang et al., 1994, Fig. 5).

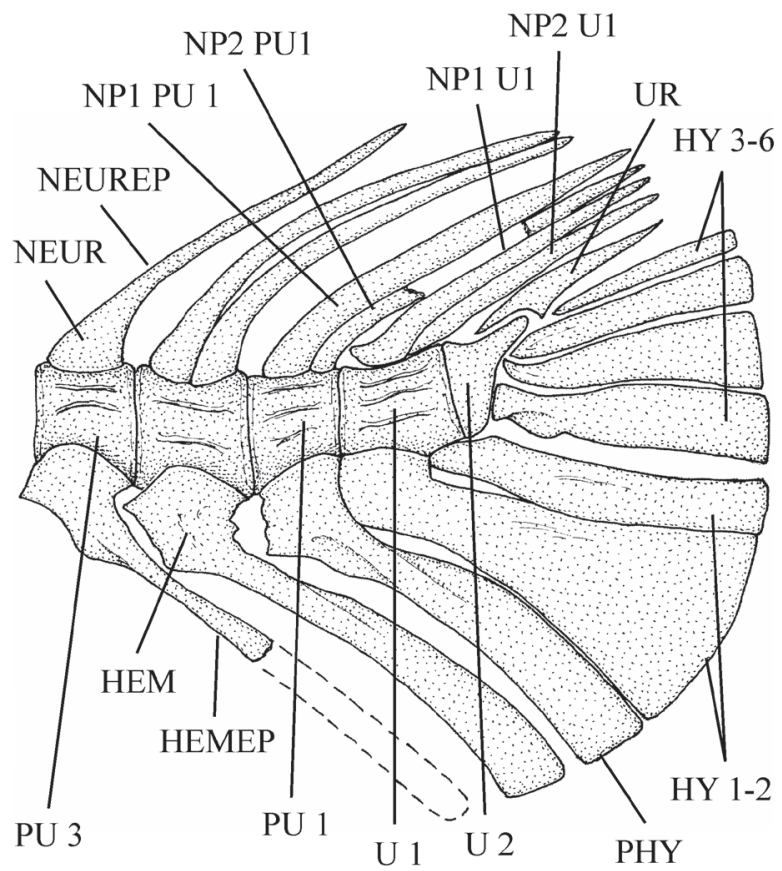

$2 \mathrm{~mm}$

Figure 16. Phareodus testis (Cope, 1877). Caudal skeleton (NHM P 7488).

Osteoglossiformes possess more derived caudal structures. The caudal skeleton of Xixiaichthys tongxinensis is the more archaic within the order (Zhang, 2004, Fig. 5C). This Chinese fossil fish has kept seven autogenous hypurals as in some Lycopteriformes but exhibits only three uroneurals, no free epural but a complete neural spine on PU 1 and U 1. HY 3 and

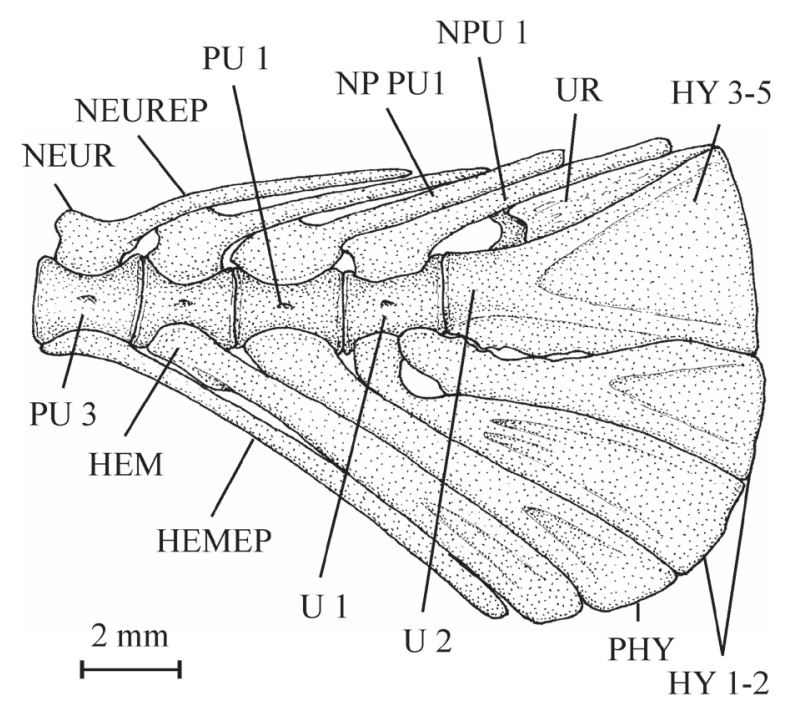

Figure 17. Osteoglossum bicirrhosum Cuvier, 1829. Caudal skeleton (IRSNB RG 1088).
4 are articulated on the ventral face of U2 which is rather long. Paralycoptera wui has a quite similar caudal skeleton but with only six hypurals and two or three uroneurals (Xu \& Chang, 2009, Fig. 9).

Within more evolved osteoglossiform fishes, two different evolutionary trends of the caudal skeleton take their rise from that primitive pattern (Fig. 20).

In Chanopsis, there are still three uroneurals and all the six hypurals are autogenous. But HY 3 is now articulated on the rear face of $U 2$ and not on its ventral face as usual in primitive teleosts. A similar pattern also occurs in some other fossil Osteoglossiformes, such as Phareodus, Musperia or Joffrichthys Li \& Wilson, 1996, but, in these fishes, U 2 is shortened and only one uroneural is preserved (Fig. 16; Greenwood, 1966, Fig. 12 [the uroneural is labelled "epural"]; Taverne, 1978, Fig. 13; Taverne, 2009b, Fig. 13; Li \& Wilson, 1996, Fig. 5 [the uroneural is labelled "epural"]; Li et al., 1997, Fig. 5 [the uroneural is labelled "epural"]; Newbrey \& Bozek, 2000, Fig. 3C), a situation more evolved than that of Chanopsis. This pattern clearly announces the specialized caudal morphology of the fossil pantodontid Prognathoglossum Taverne \& Capasso, 2012 from the marine Cenomanian of Lebanon in which HY 3 is fused to a reduced U 2 (Taverne \& Capasso, 2012, figs 11, 12). The situation is still a little more evolved in many fossil and Recent Osteoglossiformes, such as Thrissopterus Heckel, 1856, Foreyichthys, Ridewoodichthys Taverne, 2009, Pantodon Peters, 1876, Osteoglossum Cuvier, 1829, Scleropages Günther, 1864, Heterotis and Arapaima Müller, 1843, in which HY 3 to 5 are partially or totally fused together and to a reduced U 2 while HY 6 remains free (Figs 17, 18; Greenwood, 1966, figs 1-10; Taverne, 1977, figs 66, 90, 120, 143, 144; Taverne, 1978, Fig. 54; Taverne, 1998, figs 10, 14, 18; Taverne, 2009a, Fig. 4; among others). In Osteoglossum, HY 6 is lost (Fig. 17). Chanopsis holds a plesiomorphic position in regard to all those fishes.

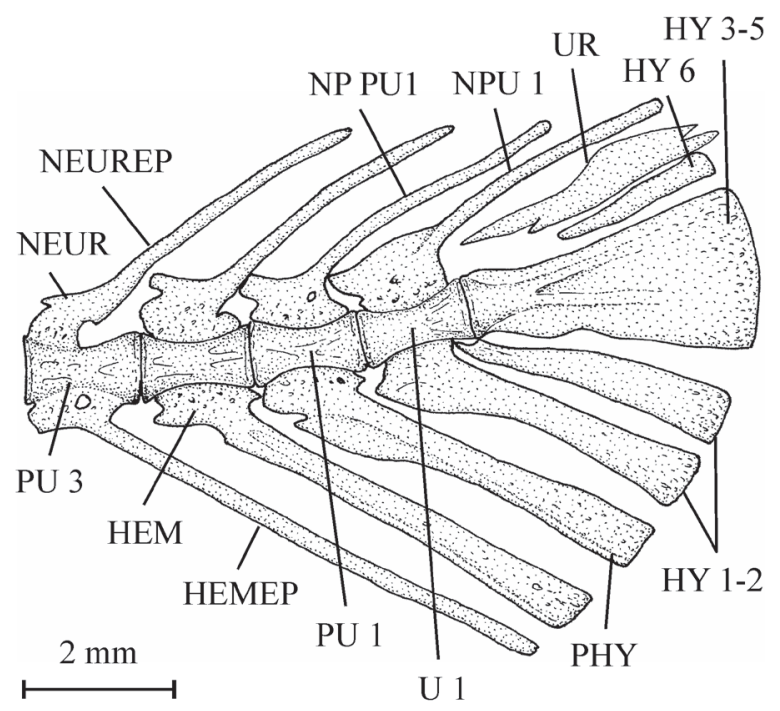

Figure 18. Pantodon buchholzi Peters, 1876. Caudal skeleton (MRAC, without number).

A few fossil osteoglossiforms, like Singida jacksonoides and Chauliopareion mahengeense, do not share these apomorphies and have preserved the archaic teleost pattern shown by Xixaichthys tongxinensis and Paralycoptera wui in which the dorsal hypurals remain unfused and articulate on the ventral face of a rather long $\mathrm{U} 2$, but the two African species exhibit only five hypurals and two uroneurals (Fig. 19; Greenwood \& Patterson, 1967, Fig. 2; Murray \& Wilson, 2005, figs 3, 5). These Eocene fossil fishes seem to represent another osteoglossiform lineage.

The presence of squamules on the scales of the genera of the first group and their absence in the members of the second 


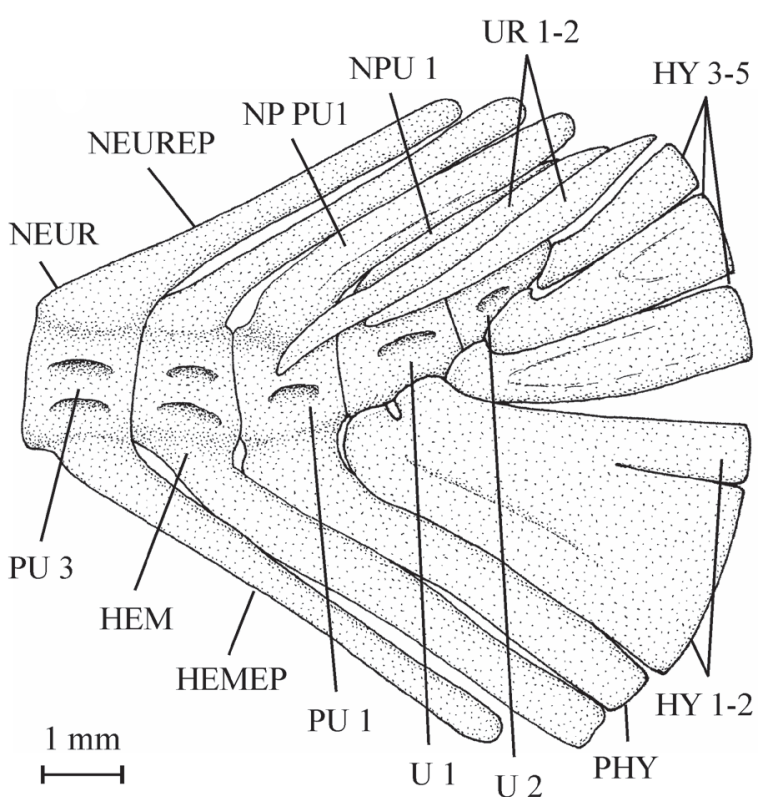

Figure 19. Singida jacksonoides Greenwood \& Patterson, 1967. Caudal skeleton (NHM P 42623a).

group (Greenwood \& Patterson, 1967, pl. 2, Fig. 2; Murray \& Wilson, 2005, p. 219) confirm that divergent evolution within Osteoglossiformes. It is to be noted that the fossil heterotinid Joffrichthys, which belongs to the first group, also lacks squamules on its scales (Li \& Wilson, 1996, p. 204; Newbrey \& Bozek, 2000 , p. 19, Fig. 6) but the Recent heterotinid Heterotis and Arapaima possess scales with squamules (Taverne, 1977, figs 121, 122, 145, 146). The Recent African genus Pantodon, also belonging to the first group, exhibits scales with only one squamule in the centre (Taverne, 1978, figs 55, 56) and sometimes without any squamule at all, as in the fossil pantodontid Prognathoglossum (Taverne \& Capasso, 2012, Fig. 13).

\section{Osteoglossiformes}

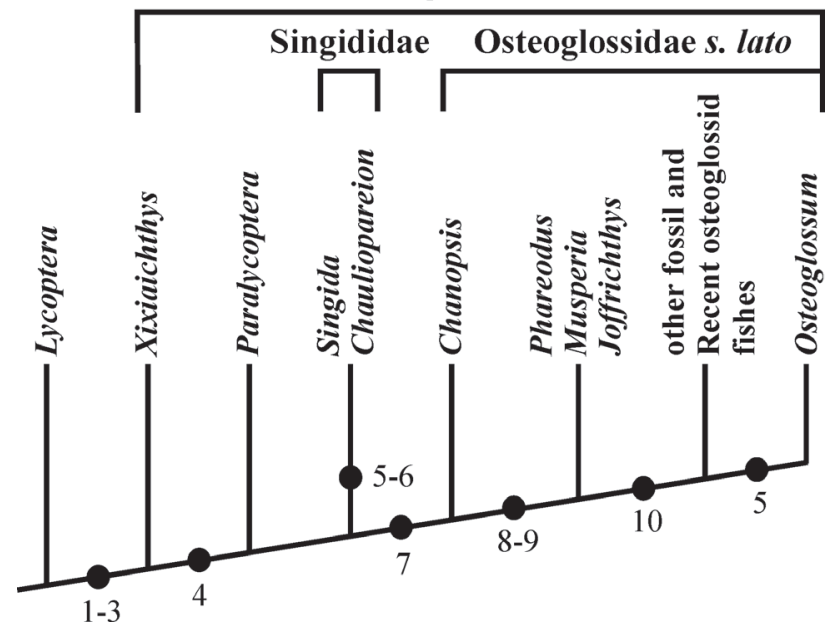

Figure 20. Diagram showing the evolution of the caudal skeleton within Osteoglossiformes. The Lower Cretaceous Chinese genus Lycoptera Müller, 1848 is chosen as outgroup. (1) Number of uroneurals reduced to three. (2) No free epural. (3) Neural spines present on PU1 and U1. (4) HY7 lost. (5) HY6 lost. (6) UR3 lost. (7) HY3 articulated on the rear of U2 and no more on its ventral face. (8) U2 greatly shortened. (9) UR2 lost. (10) HY 3, 4, 5 partly or totally fused together and with U2.

\section{Conclusions}

Chanopsis lombardi from the continental Aptian-Albian of the Democratic Republic of Congo is the most primitive and one of the oldest members of the family Osteoglossidae sensu lato (including Pantodontidae, Arapaimidae, Phareodontinae). Singididae apparently represent another lineage of osteoglossoid fishes.

\section{Acknowledgements}

I greatly thank Dr. Daniel Baudet and Dr. Florias Mees, respectively the former and the present curators of the paleontological collection of the Royal Museum of Central Africa (Tervuren), for allowing me the access to the materiel studied in the present paper, and Mr. Hugo De Potter, from the Department of Paleontology of the Royal Institute Royal of Natural Sciences of Belgium, for his technical help. I am grateful to Dr. Aurore Mathys and Dr. Emmanuel Gilissen who have performed the CTscan used for the present study. That CT-scan work is part of the AGORA 3D project financially supported by the Federal Science Policy Office of Belgium (BELSPO). Finally, I also thank Dr. Jean Gaudant (Paris) and Dr. Lionel Cavin (Geneva) who have accepted to review my manuscript.

\section{List of abbreviations used in the text-figures}

BO: basioccipital; CLT: cleithrum; COR: hypocoracoid (= coracoid sensu stricto); DETH: dermethoid (= rostral); DSPH: dermosphenotic; ECPT: ectopterygoid; ENPT: entopterygoid; EP: epural; EPI: epiotic (= epioccipital); EPIN: epineural; EXO: exoccipital; FR: frontal; HCLT: hypercleithrum (= supracleithrum); HEM: haemal arch; HEMAP: haemapophysis; HEMEP: haemal spine; HY 1-7: hypurals 1 to 7; HYOM: hyomandibular; IC: intercalary; IOP: interopercle; IORB 2-4: infraorbitals 2 to 4; LEP: fin ray; MPT: metapterygoid; NA: nasal; NEUR: neural arch; NEUREP: neural spine; NP PU1: neural spine of preural vertebra 1; NP1 PU1: first neural spine of preural vertebra 1; NP2 PU1: second neural spine of preural vertebra 1; NP U1 (p.): (posterior) neural spine of ural vertebra 1; NP1 U1: first neural spine of ural vertebra 1; NP2 U1: second neural spine of ural vertebra 1: OSPH: orbitosphenoid; PA: parietal; PAL: palatine; PCLT: postcleithrum; PHY: parhypural; POP: preopercle; PRO: prootic; PS: parasphenoid; PSPH: pleurosphenoid; PTE: pterotic; PU 1-4: preural vertebrae 1 to 4; QU: quadrate; SCA: hypercoracoid (= scapula); SOC: supraoccipital; SOP: subopercle; SPH: sphenotic (= autosphenotic); SY: symplectic; U 1 (a., p.), 2: (anterior, posterior) ural vertebrae 1 and 2; V: vertebra; $b$. pr.: basipterygoid process of the parasphenoid; circ.: circuli; d. f.: dilatator fossa; f. V.: foramen for the trigeminal nerve ( $V$ ); f. ef. ps. a.: foramen for the efferent pseudobranchial artery; f. i. c.: foramen for the internal carotid; f. t. h. VII: foramen for the truncus hyoideomandibularis of the facial nerve (VII); gr. V, VII: groove for the trigeminal and facial nerves (V, VII); gr. j. V.: groove for the jugular vein; ic. br: intercalary bony bridge over the subtemporal fossa; o.-d. f.: occipito-dorsal fossa; ot. c.: otic (postorbital) sensory canal; po. pr.: postorbital process of the sphenotic; psq: pre-squamules; rad.: radii; sorb. c.: supraorbital sensory canal; sq.: squamules; t. f.: temporal fossa.

\section{References}

Bardack, D., 1965. Anatomy and evolution of chirocentrid fishes. The University of Kansas, Paleontological Contributions, Vertebrata, 10, $1-88$.

Bonde, N., 2008. Osteoglossomorphs of the marine Lower Eocene of Denmark - with remarks on other Eocene taxa and their importance for paleobiogeography. In Cavin, L., Longbottom, A. \& Richter, M. (eds), Fishes and the Break-up of Pangaea. Geological Society, London, Special Publications, 295, 253-310.

Cahen, L., Ferrand, J.J., Haarsma, M.J.F., Lepersonne, J. \& Verbeek, Th., 1959. Description du sondage de Samba. Annales du Musée Royal du Congo Belge, série in- $8^{\circ}$, Sciences géologiques, 29, 1-210.

Cahen, L., Ferrand, J.J., Haarsma, M.J.F., Lepersonne, J. \& Verbeek, Th., 1960. Description du sondage de Dekese. Annales du Musée Royal du Congo Belge, série in- $8^{\circ}$, Sciences géologiques, 34, 1-115.

Cahen, L. \& Lepersonne, J., 1954. Etat actuel des connaissances relatives 
aux séries mésozoïques de l'intérieur du Congo. Bulletin de la Société belge de Géologie, de Paléontologie et d'Hydrologie, 63, 20-37.

Casier, E., 1961. Matériaux pour la faune ichthyologique éocrétacique du Congo. Annales du Musée Royal de 1'Afrique Centrale, série in- $8^{\circ}$, Sciences géologiques, 39, 1-96.

Casier, E., 1969a. Addenda aux connaissances sur la faune ichthyologique de la série de Bokungu (Congo). Annales du Musée Royal de l'Afrique Centrale, série in- $8^{\circ}$, Sciences géologiques, 62, 1-20.

Casier, E., 1969b. Sur les conditions de dépôt de quelques-unes des formations mésozoïques du Bassin du Congo. Annales du Musée Royal de 1'Afrique Centrale, série in- $8^{\circ}$, Sciences géologiques, 62 , 27-47.

Colin, J.-P., 1994. Mesozoic-Cenozoic lacustrine sediments of the Zaïre Interior Basin. In Gierlowski-Kordesch, E. \& Keltz, K. (eds), Global Geological Record of Lake Basins, Vol. 1, I. G. C. P. Project 324. Cambridge University Press, Cambridge,, 31-36.

Defretin-Lefranc, S., 1967. Etude sur les phyllopodes du Bassin du Congo. Annales du Musée Royal de l'Afrique Centrale, série in- $8^{\circ}$, Sciences géologiques, 56, 1-122.

Greenwood, P.H., 1966. The caudal fin skeleton in osteoglossoid fishes. Annals and Magazine of Natural History, series 13, 9, 581-597.

Greenwood, P.H., 1970. On the genus Lycoptera and its relationship with the family Hiodontidae (Pisces, Osteoglossomorpha). Bulletin of the British Museum (Natural History), Zoology, 19/8, 259-285.

Greenwood, P.H. \& Patterson, C., 1967. A fossil osteoglossoid fish from Tanzania (E. Africa). Journal of the Linnean Society (Zoology), 47/311, 211-223.

Grekoff, N., 1957. Ostracodes du Bassin du Congo. I. Jurassique supérieur et Crétacé inférieur du nord du bassin. Annales du Musée Royal du Congo Belge, série in- $8^{\circ}$, Sciences géologiques, 19, 1-97.

Grekoff, N., 1960. Ostracodes du Bassin du Congo. II. Crétacé. Annales du Musée Royal du Congo Belge, série in $-8^{\circ}$, Sciences géologiques, $35,1-71$.

Lepersonne, J., 1977. Structure géologique du bassin intérieur du Zaïre. Académie Royale de Belgique, Bulletin de la Classe des Sciences, $5^{\mathrm{e}}$ série, 63/12, 941-965.

Li, G.-Q., 1994. Systematic position of the Australian fossil osteoglossid fish + Phareodus (= Phareoides) queenslandicus Hills. Memoirs of the Queensland Museum, 37/1, 287-300.

Li, G-Q., 1996. A new species of Late Cretaceous osteoglossid (Teleostei) from the Oldman Formation of Alberta, Canada, and its phylogenetic relationships. In Arratia, G. \& Viohl, H.-P. (eds), Mesozoic Fishes - Systematics and Paleoecology. Verlag Dr. F. Pfeil, München, 285298.

Li, G.-Q. \& Wilson, M.V.H., 1996. The discovery of Heterotidinae (Teleostei, Osteoglossidae) from the Paleocene Paskapoo Formation of Alberta, Canada. Journal of Vertebrate Paleontology, 16/2, 198209.

Li, G.-Q., Grande, L. \& Wilson, M.V.H., 1997. The species of Phareodus (Teleostei, Osteoglossidae) from the Eocene of North America and their phylogenetic relationships. Journal of Vertebrate Paleontology, 17/3, 487-505.

Maheshwari, H.K., Bose, M.N. \& Kumaran, K.P.N., 1977. Mesozoic sporae dispersae from Zaïre. II. - The Loia and Bokungu groups in the Samba Borehole. Annales du Musée Royal de l'Afrique Centrale, série in- $8^{\circ}$, Sciences géologiques, $80,1-43$.

Murray, A.M. \& Wilson, M.V.H., 2005. Description of a new Eocene osteoglossid fish and additional information on Singida jacksonoides Greenwood and Patterson, 1967 (Osteoglossomorpha), with an assessment of their phylogenetic relationships. Zoological Journal of the Linnean Society, 144, 213-228.

Newbrey, M.G. \& Bozek, M.A., 2000. A new species of Joffrichthys (Teleostei: Osteoglossidae) from the Sentinel Butte Formation, (Paleocene) of North Dakota, USA. Journal of Vertebrate Paleontology, 20/1, 12-20.

Pinto, I.D. \& Sanguinetti, Y.T., 1962. A complete revision of the genera Bisulcocypris and Theriosynoecum (Ostracoda) with the world geographical and stratigraphical distribution (including Metacypris, Elpidium, Gomphocytera and Cytheridella). Grafia da Universidade do Rio Grande do Sul, Publicacao Especial, 4, 1-165.

Roellig, H.F., 1967. The Osteoglossidae, fossil and recent. Columbia University, Geology, Ph. D., University Microfilms, Inc., Ann Arbor, Michigan, $228 \mathrm{p}$.

Taverne, L., 1974. Sur la présence d'organes cérébraux inconnus chez l'Ostéoglossidé africain Heterotis (Ehrenberg) Cuvier et Valenciennes, 1846. Académie Royale de Belgique, Bulletin de la Classe des Sciences, 5e série, 60/3, 346-349.

Taverne, L., 1975. A propos de trois téléostéens salmoniformes fossiles du Crétacé inférieur (Wealdien) du Zaïre, précédemment décrits dans les genres Leptolepis et Clupavus (Pisces, Teleostei). Revue de Zoologie Africaine, 89/3, 481-504.

Taverne, L., 1977. Ostéologie, phylogénèse et systématique des téléostéens fossiles et actuels du super-ordre des Ostéoglossomorphes. Première partie. Ostéologie des genres Hiodon, Eohiodon, Lycoptera, Osteoglossum, Scleropages, Heterotis et Arapaima. Académie Royale de Belgique, Mémoires de la Classe des Sciences, collection in- $8^{\circ}, 2^{\mathrm{e}}$ série, $42 / 3,1-235$.

Taverne, L., 1978. Ostéologie, phylogénèse et systématique des téléostéens fossiles et actuels du super-ordre des Ostéoglossomorphes. Deuxième partie. Ostéologie des genres Phareodus, Phareoides, Brychaetus, Musperia, Pantodon, Singida, Notopterus, Xenomystus et Papyrocranus. Académie Royale de Belgique, Mémoires de la Classe des Sciences, collection in- $8^{\circ}$, 2e série, 42/6, 1-213.

Taverne, L., 1984. A propos de Chanopsis lombardi du Crétacé inférieur du Zaïre (Teleostei, Osteoglossiformes). Revue de Zoologie Africaine, 98/3, 578-590.

Taverne, L., 1998. Les ostéoglossomorphes marins de l'Éocène du Monte Bolca (Italie): Monopteros Volta, 1796, Thrissopterus Heckel, 1856 et Foreyichthys Taverne, 1979. Considérations sur la phylogénie des téléostéens ostéoglossomorphes. Studi e ricerche sui giacimenti terziari di Bolca, 7, Miscellanea Paleontologica, Museo Civico di Storia Naturale, Verona, 67-158.

Taverne, L., 2009a. Ridewoodichthys, a new genus for Brychaetus caheni from the marine Paleocene of Cabinda (Africa): redescription and comments on its relationships within the Osteoglossidae (Teleostei, Osteoglossomorpha). Bulletin de l'Institut Royal des Sciences Naturelles de Belgique, Sciences de la Terre, 79, 147-153.

Taverne, L., 2009b. New insights on the osteology and taxonomy of the osteoglossid fishes Phareodus, Brychaetus and Musperia (Teleostei, Osteoglossomorpha). Bulletin de l'Institut Royal des Sciences Naturelles de Belgique, Sciences de la Terre, 79, 175-190.

Taverne, L. \& Capasso, L., 2012. Osteology and relationships of Prognathoglossum kalassyi gen. and sp. nov. (Teleostei, Osteoglossiformes, Pantodontidae) from the marine Cenomanian (Upper Cretaceous) of En Nammoura (Lebanon). Cybium, 36/4, 563-574.

Xu, G.-H. \& Chang, M.-M., 2009. Redescription of Paralycoptera wui Chang \& Chou, 1977 (Teleostei: Osteoglossoidei) from the Early Cretaceous of eastern China. Zoological Journal of the Linnean Society, 157, 83-106.

Zhang, J.-Y., 2004. New fossil osteoglossomorph from Ningxia, China. Journal of Vertebrate Paleontology, 24/3, 515-524.

Zhang, J.-Y., Jin, F. \& Zhou, Z., 1994. A review of Mesozoic osteoglossomorph fish Lycoptera longicephalus. Vertebrata PalAsiatica, 32/1, 41-59. [In Chinese with English summary].

\section{Addendum}

During the time the present paper was in press, an isolated hyomandibula of a second osteoglossid fish from the continental Lower Cretaceous of the Dem. Rep. of Congo has been discovered and published (Taverne, 2016). This fish is much smaller than Chanopsis and its hyomandibula differs from that of Chanopsis by its extremely long opercular process.

Taverne, L., 2016. On the presence of a second osteoglossid fish (Teleostei, Osteoglossiformes) in the continental Lower Cretaceous of the Democratic Republic of Congo (Central Africa). Geo-Eco-Trop, 39 [2015] /2, 247-254.

Manuscript received 24.04.2014, accepted in revised form 24.02.2016, available on line 03.11.2016. 